\title{
健診データの図表化出力 (第二報)
}

\author{
折茂淳
}

臨床検査データより個人の健康度の指標を求め, その 受喨者に理解しやすい形で提示するための検討を行な い, 臓器疾患別に異常を反映すると考えられる検査項目 を組み合わせ, 検査項目の異常の程度に応じてポイント を加算してゆく事により得られる「疾患スコア」という 指標と, 疾患スコアの值に応じてコンピュータの CRT 画面上に描いた人体の模式図の特定の部位の模様や色調 を変化させて示す「疾患マップ」という図表を考案し， 昨年の本大会及び学会誌に報告した。今回はてれをさら に実用的なものにするため, 検査項目の見直しや専用報 告書の作成等の改良を行ない，統計的な検討も加えたの で報告する。対象は職域健診受診者 780 名とし, 解析は パーソナルコンピュータ, キヤノン AS-100 システム を使用した。

検査項目は従来の 53 項目から生化学血清学検査 21 項 目, 血算 5 項目, 尿一般検査 4 項目及び血圧の 32 項目 とし, 対象となる疾患スコアも従来の 9 種類から全身状 態, 代謝性疾患, 造血器系疾患, 循環器系疾患, 肝胆道 疾患, 膵疾患, 腎疾患の 7 種類とした。これらの改良を 行なった際には, 異常者の検出率が適切な割合となる様 に留意しながらより検出に有効な検査項目を選択し, 検出率に影響を与えない項目や，従来は含まれていた CEA や AFP のような二次スクリーニング項目とした 方がよいものは除外し, 疾患スコアを求める際の検査項 目の組み合わせも検査項目の重複を最小限とした。これ らの改良の結果, 検査項目もごく一般的な項目となり, 大半が自動化されている項目でもあり，検査コストも低 くする事が可能となった。疾患スコアで見た異常值の出 現率はそれぞれの疾患スコアで軽度異常が $8 \%$ 程度, 中 程度異常が $2 \sim 4 \%$, 高度異常が 0.5〜 1\%ととなり 二次検査の指示等を行なう際により有用な值となった。

一方, 疾患スコアの值と統計学的な解析結果との関係

\section{Graphical Output of Health Testing Data (2 nd Report) \\ 日本動態機構研究所}

を調べるために検査データをもとに行なった因子分析の 結果と比較した。まず検査データをあとに因子分析を行 ない 17 の因子を抽出し, それぞれの因子評点を求め た。これらと疾患スコアの值との相関を求めたところ, 例えば全身状態の疾患スコアと蛋白代謝機能を中心とし た全身状態を反映する因子や間葉系の機能を反映する因 子との間に相関が認められるなど, 統計学的な解析結果 と疾患スコアとの間に妥当な関係があることが確かめら れた。

結果の出力も, より受診者に理解しやすい形式でデー タを示すという観点から改良を加えた。今回新たに作成 した専用の報告書では従来, ややあすると冷たいイメー ジを与えがちな結果報告書のイメージを変えるために暖 色系の多色刷の報告書とし, データや図表の読み方につ いて屯, 受診者に理解されやすいように, できるだけ専 門用語を使わない説明を加えるなどの配慮を行なった。 疾患スコアについても, 従来は疾患スコアの数值を報告 書に示し説明を加えていたが，例えば全身状態の疾患ス コアが 1.5 ならば「全身状態に軽度の異常の可能性があ ります」といったような漢字コメントに変換して出力す るととにより受診者の理解度が向上した。

今回改良を加えたデータの解析, 報告システムは, 比 較的低コストで実施可能であり, さらに検査データをコ ンピュータで解析し, 効率的に異常者をピックアップす る事ができるため，一定の基準での二次スクリーニング の実施や生活指導等が行ないやすく, 職域健診や地域健 診のような多人数を対象とする健診において有用なシス テムであると考える。また，受診者に対してもわかりや すいデータが報告される事により自己の健康への関心が 高まり，健診への参加も積極的になるなどの利点があ る。今後はさらに有用で, 理解されやすい解析, 出力方 法を考え, 時系列的なデータの出力形式む検討してゆき たい。 